DOI https://doi.org/10.18551/rjoas.2018-11.20

\title{
THE ROLE OF BRAND IMAGE MEDIATING THE EFFECT OF PRODUCT QUALITY ON REPURCHASE INTENTION
}

\author{
Yasa I Ketut \\ Politeknik Negeri Bali, Indonesia \\ E-mail: yasa iketut@yahoo.com
}

\begin{abstract}
Repurchase intention is a consumer action to buy back a product because of the satisfaction received after the previous purchase; so that consumers feel satisfied a company needs to pay attention to the factors that affect the repurchase intention. This study aims to determine the role of brand image to mediate the effect of product quality on the re-purchase intention on Adidas brand shoes in Denpasar City. This research was conducted in Denpasar City area by disseminating 120 questionnaires. Data collection method used is purposive sampling method. Data collection is done through the spread of questionnaires online and offline in the field. The analysis technique used is path analysis. Based on the results of research show that product quality has positive and significant effect to brand image. Product quality has a positive and significant effect on the repurchase intention. Brand image has a positive and significant effect on the repurchase intention. Brand image as a mediation variable has significant effect through product quality to repurchase intention by partial.
\end{abstract}

\section{KEY WORDS}

Brand image, product, quality, repurchase intention.

The company is required to continue to improve product quality and continue to innovate to create a variety of product innovations that are able to meet the needs and desires of the community. Companies need to learn and identify factors that will direct the company to success (Fouladivanda et al., 2013). Companies must be able to provide quality that is in accordance with the needs and desires of consumers by taking into account the existing market quality standards (Puspita et al, 2016). The reasons for improving product quality can be shown to maintain the existence of a company even to win business competition. One of them is the competition in the sports shoes market in Indonesia. Indonesia has a local shoe brand that is able to compete with shoe brands from outside and with the presence of outside and local brands that enliven the sports shoes market in Indonesia, the competition in this business is getting tighter.

Before consumers use a product to buy, consumers tend to rely on information from other people who have already purchased the product. Consumer decisions in deciding to choose a brand or buying a product cannot be separated from consumer behavior that is influenced by many factors (Widyastuti and Alwani, 2018). Consumers will use their judgment in determining and making their decisions, especially when buying quality products (Ackaradejruangsri, 2013). If this is not appropriate for them, then they will reject the product (Khraim, 2011).

According to Musay (2013), brand image is an image or impression caused by a brand in the customer's mind. Brand image according to (Roslina, 2010) is a guide that will be used by consumers to evaluate products when consumers do not have sufficient knowledge about a product. When a consumer obtains satisfaction on a previous purchase, there is an increase in the positive thinking of the consumer towards the product or service (Halim et al., 2014). A good brand image will make it easier for consumers to recognize a product and create a good perception of product quality and allow consumers to make purchase intentions and even repurchase the product. Chen et al., (2013) found that marketing can provide the right brand strategy for consumers according to different segments to positively strengthen brand associations. According to Ranto (2013), building a brand has become a necessity for companies to be able to compete with other companies. 
This research was conducted based on several findings from previous research on the influence of brand image, product quality and repurchase intention with different results. The results of research from Ramadhan and Sentosa (2017) state that product quality does not have a significant effect on repurchase intention. This is in line with the results of Bahar and Herman's (2015) study stating that product quality has no significant effect on repurchase intention, because $t$-value is less than t-table $(0.100>1.293)$ and significant level greater than $0.05(0.921<0.05)$ so that product quality does not have a significant partial effect on repurchase interest. This result contrasts with the research of Aryadhe and Rastini (2016) which states that product quality and brand image have a positive influence on repurchase intention. This is in line with Yunus's research results (2014), product quality has a significant effect on repurchase intention.

\section{LITERATURE REVIEW}

Product Quality. Kotler and Armstrong (2012: 283) define product quality as the ability of a product to demonstrate its function, this includes overall durability, reliability, accuracy, ease of operation and product repair, as well as other product attributes. Consumers want the product they buy according to their wishes or the product is quality. The higher the quality of the product, the higher the consumer's decision to make a purchase (Idris, 2013). Ehsani (2015) states that product quality is the customer's perception of the overall quality or superiority of a product or service, in relation to its purpose, relative to alternatives.

Brand Image. Kotler and Keller (2012: 274) brand image is a public perception of the company or its products. Image or image itself is a picture, likeness of the main impression or outline even the shadow that someone has about something. Brand image is a perception and belief in a group of brand associations that occur in the minds of consumers (Sari, 2013). According to Adil (2012) the main function of brand image is to answer questions about how consumers choose between alternative brands after taking information. According to Evelina et al. (2013), brand image is a representation of the overall perception of the brand and is formed from past information and experience of the brand. Therefore the image or image can be maintained. This contains the interpretation of the target market for product attributes, benefits, situation of use, users, and characteristics of the manufacture or market. (Rizan et al., 2012) suggests that brand image is an assumption about brands that consumers reflect that hold on to consumers' memories.

Repurchase Intention. According to Hasan (2013: 173) interest in buying is the tendency of consumers to buy a brand or take actions related to purchasing as measured by the level of possible consumers to make purchases to predict consumer behavior in the future. Repurchase intention is part of consumer buying behavior where the suitability between the performance of the product or service offered by the company produces consumer interest to consume it again in the future (Wijaya, 2015). Ain and Ratnasari (2015) stated that repurchase intention was a post-purchase action caused by the satisfaction felt by consumers for products that had been purchased or consumed before. The intention to repurchase is a consumer commitment that is formed after the consumer purchases a product or service.

Hypothesis:

Product quality to brand image. Consumers will assess a high quality product if it has these elements and of course this can show its ability to meet consumer needs and in accordance with their expectations of the product. The quality of a product can affect consumers in the formation of a brand image. If the product quality of a brand is sold high, then consumers will associate high product quality to the brand, which means that the brand image is good. Product quality becomes very important because it involves consumer confidence in the product and the company itself because good quality will give birth to a positive image in the minds of consumers so that consumers believe in the product (Anis et al, 2015). If the quality of the product is good in the eyes of consumers, then a positive brand image is formed automatically in the eyes of consumers. Based on the results of previous studies suggested that product quality has a significant positive effect on brand image 
(Noerchoidah, 2013; Yusmawan et al., 2014). Laura and Siska (2017), stated that product quality positively influences positively the brand image.

$\mathrm{H}_{1}$ : Product quality has a positive and significant effect on brand image.

Product quality to repurchase intention. According to Kotler and Armstrong (2014: 347) product quality is the ability of a product to perform its functions, this capability includes durability, reliability, accuracy produced, ease of operation and repair, and other valuable attributes in the overall product. In the results of Zulfadly's research (2013) in his research entitled "The Effect of Product Quality, Price and Brand Image on the Decision to Repurchase Yakult Products in Padang City" shows the results that product quality has a significant effect on repurchase decisions. Another study was also conducted by Saidani and Arifin (2012) which showed that product quality had a positive and significant effect on repurchase interest. Based on the results of the study that the quality of products has the greatest influence, the quality of products is increasingly maintained and enhanced, it will create a high repurchase intention.

$\mathrm{H}_{2}$ : Product quality has a positive and significant effect on repurchase intention.

Brand image to repurchase intention. Tariq et al., (2013) states that brand image is a very important aspect of purchase intention. This helps consumers to decide whether the chosen brand is a better choice for them and they are forced to make purchase intentions several times. A good image helps to create a long-term relationship between the product and the end user. This happens when consumers feel satisfied with the product / service received from a company that provides goods / services so it is very likely for consumers to make a repeat purchase. Ain and Ratnasari (2015), stated that a strong and positive brand image will increase consumer repurchase intention, otherwise if the brand image is not good, then repurchase intention will decrease. Thakur and Singh (2012) stated that there was a positive relationship between brand image and consumer repurchase intention for a brand or product. Brand image is formed through various attributes with the aim of one of them is to form a positive attitude towards a brand and generate intention to buy the brand, in other words, brand image has a significant effect on repurchase intention.

$\mathrm{H}_{3}$ : Brand image has a positive and significant effect on repurchase intention.

The role of brand image mediating the effect of product quality on repurchase intention. Based on research conducted by Anggitan (2013) shows that product quality has a direct positive influence with repurchase intentions indirectly through brand image. This is similar to the results of a research test conducted by Andriadi and Untarini (2013) that the brand image in one dimension has a significant influence that can form consumer repurchase intention. Aryadhe and Rasini (2016) in their research findings found that product quality through brand image has a positive and significant effect on repurchase intention. intention.

$\mathrm{H}_{4}$ : Brand image has a positive effect mediating on product quality against repurchase

\section{METHODS OF RESEARCH}

The location of this study was conducted on consumers who had already bought and used Adidas brand shoes in Denpasar City. The city of Denpasar was chosen as the location of the study because of the consideration that this location was the center of the city in Bali with a rapid economic sector growth. In addition, a dense population and a fairly high population that reflects the lifestyle of Balinese people who are updating the needs of new products, especially fashion products such as shoes used daily. The object in this study is the influence of product quality $(\mathrm{X})$ on brand image $(\mathrm{Y} 1)$, the influence of product quality $(\mathrm{X})$ on repurchase intention (Y2), the influence of brand image $(Y 1)$ on repurchase intention $(Y 2)$, and brand influence image $(\mathrm{Y} 1)$ mediates product quality $(\mathrm{X})$ and repurchase intention $(\mathrm{Y})$. The population in this study was consumers who had already bought or used Adidas brand shoes in Denpasar City. The sample determination method used in this research is non probability sampling.

This research uses path analysis techniques or commonly called path analysis. Path analysis or path analysis is an extension of statistical analysis developed from multiple 
regressions. According to Riduwan and Kuncoro (2011: 2) the path analysis model is used to analyze the pattern of relationships between variables in order to determine the direct and indirect effects of a set of exogenous variables (product quality) on endogenous variables (repurchase intention). In this analysis the main subject is the variables that have a correlation and the model of the relationship between these variables is predetermined by the researcher. The basis for calculating the path coefficient is the correlation and regression analysis in the calculation using software with SPSS 24.00 for windows program.

\section{RESULTS AND DISCUSSION}

According to age grouping, the majority of respondents aged $20-25$ years were $62.5 \%$, then respondents aged over 25 years were $16.7 \%$ and respondents under 20 years old were $20.8 \%$. Judging from the gender of the respondents, women dominated by $52.5 \%$ and men by $47.5 \%$.

Testing the data in this study uses Path Analysis technique, where path analysis is an extension of multiple linear regression analysis to test the causality relationship between 2 or more variables. Stages do path analysis techniques, namely:

Sub-structural Equation 1:

$$
Y_{1}=\beta_{1} X+e 1
$$

Sub-structural Equation 2:

$$
Y_{2}=\beta_{2} X+\beta_{3} Y_{1}+e 2
$$

Path coefficient calculation is done by regression analysis through SPSS 24.0 for Windows software, obtained the results shown in Tables 1 and 2.

\begin{tabular}{|c|c|c|c|c|c|}
\hline Model & \multicolumn{2}{|c|}{ Unstandardized Coefficients } & \multirow{2}{*}{$\begin{array}{c}\text { Standardized Coefficients } \\
\text { Beta }\end{array}$} & \multirow[t]{2}{*}{$\mathrm{t}$ hitung } & \multirow[t]{2}{*}{ Sig. } \\
\hline & $B$ & Std.Error & & & \\
\hline 1 (Constant) & 4,363 & 1,085 & & 4,020 & 0,000 \\
\hline Product quality & 0,488 & 0,042 & 0,734 & 11,734 & 0,000 \\
\hline R1 Square & & & & & 0,538 \\
\hline $\mathrm{F}$ & & & & & 137,683 \\
\hline Sig. & & & & & 0,000 \\
\hline
\end{tabular}

Table 1 - Model I

Source: Primary data, 2018.

$$
\begin{gathered}
Y_{1}=\beta_{1} X+\varepsilon_{1} \\
Y_{1}=0,734 X+\varepsilon_{1}
\end{gathered}
$$

The value of $\beta_{1}$ is 0.734 meaning that Product Quality has a positive effect on Brand

\begin{tabular}{|c|c|c|c|c|c|}
\hline \multirow[t]{2}{*}{ Model } & \multicolumn{2}{|c|}{ Unstandardized Coefficients } & \multirow{2}{*}{$\begin{array}{c}\text { Standardized Coefficients } \\
\text { Beta }\end{array}$} & \multirow[t]{2}{*}{$\mathrm{t}_{\text {hitung }}$} & \multirow[t]{2}{*}{ Sig. } \\
\hline & $B$ & Std.Error & & & \\
\hline 1 (Constant) & 0,559 & 1,952 & & 0,286 & 0,775 \\
\hline Product quality & 0,240 & 0,103 & 0,229 & 2,319 & 0,022 \\
\hline Brand image & 0,794 & 0,155 & 0,504 & 5,111 & 0,000 \\
\hline R1 Square & & & & & 0,475 \\
\hline$F$ & & & & & 52,983 \\
\hline Sig. & & & & & 0,000 \\
\hline
\end{tabular}
Image, in other words if the Product Quality increases, it will lead to an increase in the Brand Image of Adidas brand shoes.

Table 2 - Model II

Source: Primary data, 2018. 


$$
\begin{gathered}
Y_{2}=\beta_{2} X+\beta_{3} Y_{1}+\varepsilon_{2} \\
Y_{2}=0,229 X+0,504 Y_{1}+\varepsilon_{2}
\end{gathered}
$$

Based on these equations it can be concluded that the value of $\beta_{2}$ is 0.229 , meaning that product quality has a positive effect on repurchase intention, in other words, if the product quality factor increases, it will lead to an increase in repurchase intention of Adidas brand shoes in Denpasar City. The value of $\beta_{3}$ is 0.504 meaning that the brand image has a positive effect on repurchase intention, in other words if the brand image increases there will be an increase in repurchase intention on the Adidas brand shoes in Denpasar City.

Based on substructure model 1 and substructure 2, the final path diagram model can be arranged. Before preparing the final path diagram model, the standard error value is calculated as follows:

$$
\begin{gathered}
\mathrm{Pe}_{\mathrm{i}}=\sqrt{1-\mathrm{R}_{\mathrm{i}}^{2}} \\
\mathrm{Pe}_{1}=\sqrt{1-R_{1}^{2}}=\sqrt{1-0,538}=0,679 \\
\mathrm{Pe}_{2}=\sqrt{1-R_{2}^{2}}=\sqrt{1-0,475}=0,724
\end{gathered}
$$

Based on the calculation of the effect of error $\left(\mathrm{Pe}_{1}\right)$, the result of the error $\left(\mathrm{Pe}_{1}\right)$ was 0.679 and the effect of error $\left(\mathrm{Pe}_{2}\right)$ was 0.724 . The results of the total determination coefficient are as follows:

$$
\mathrm{R}_{\mathrm{m}}^{2}=1-\left(\mathrm{Pe}_{1}\right)^{2}\left(\mathrm{Pe}_{2}\right)^{2}=0,759
$$

The total determination value of 0.759 means that $75.9 \%$ of the variation in repurchase intention is influenced by variations in product quality and brand image, while the remaining $24.1 \%$ is explained by other factors not included in the model.

The amount of direct influence and indirect influence and the total effect between variables. Calculation of influences between variables is found in Table 3 as follows.

Table 4 - Direct, Indirect and Total Effect Product Quality, Brand Image and Repurchase Intention

\begin{tabular}{llll}
\hline Model & Direct Effect & Indirect effect through brand image $\left(\mathrm{Y}_{1}\right)(\beta 1 \times \beta 3)$ & Total Effect \\
\hline $\mathrm{X}_{1} \rightarrow \mathrm{Y}_{1}$ & 0,734 & - & 0,734 \\
$\mathrm{X}_{1} \rightarrow \mathrm{Y}_{2}$ & 0,229 & 0,369 & 0,598 \\
$\mathrm{Y}_{1} \rightarrow \mathrm{Y}_{2}$ & 0,504 & - & 0,504 \\
\hline
\end{tabular}

Source: Primary data, 2018.

The effect of product quality on brand image shows that product quality has a significant positive effect on brand image. This means that the better the quality of the products provided by Adidas brand shoes, it will increase the brand image of Adidas brand shoes. The results of this study support the findings of (Noerchoidah, 2013; Yusmawan et al., 2014). Laura and Siska (2017), stated that product quality positively influences significantly the brand image.

The effect of product quality on repurchase intention indicates that product quality has a significantly positive effect on repurchase intention. This means that the better the quality of the products provided by Adidas brand shoes, it will increase the consumers' repurchase intention in Adidas brand shoes. The results of this study support the findings of previous studies Zulfadly (2013), Saidani and Arifin (2012) which show that product quality has a positive and significant effect on repurchase intention.

The effect of brand image on repurchase intention indicates that brand image has a significant positive effect on repurchase intention. This means that the better the brand image given by the Adidas brand shoes, the higher the intention to repurchase the Adidas brand shoes in Denpasar City. The results of this study support the findings of previous 
studies Ain and Ratnasari (2015), stating that a strong and positive brand image will increase consumer repurchase intention, on the contrary if the brand image is not good, then repurchase intention will decrease. Thakur and Singh (2012) stated that there was a positive relationship between brand image and consumer repurchase intention for a brand or product.

The role of brand image in mediating product quality on repurchase intention shows that brand image is able to mediate the influence of product quality on repurchase intention. This means that the brand image mediates the effect of product quality on partial repurchase intentions. In other words, brand image strengthens the influence of product quality on repurchase intention. The results of this study support the findings of Anggitan (2013), Andriadi and Untarini (2013) and Aryadhe and Rasini (2016), namely the quality of products through brand image has a positive and significant effect on repurchase intention.

\section{CONCLUSSION AND SUGGESTIONS}

This shows that the better quality of products on Adidas brand shoes will increase the brand image of Adidas brand shoes in Denpasar City. Product quality has a positive and significant effect on repurchase intention. This shows that the better quality of the product on the Adidas brand shoes will increase the repurchase intention of consumers of Adidas brand shoes in Denpasar City. Brand image has a positive and significant effect on repurchase intention. This shows that the better the brand image of the Adidas brand shoes, the higher the intention to repurchase the consumers of Adidas brand shoes in Denpasar City. Brand image can mediate the influence of product quality on repurchase intention. This shows that brand image mediates the effect of product quality on partial repurchase intentions. In other words, brand image strengthens the influence of product quality to repurchase intention.

The advice that can be put forward in this research is that Adidas producers are expected to give special prices to customers and can improve and maintain the brand image so that Adidas has a positive image, because brand image can attract consumers to buy a product. The quality of the Adidas product's durability needs to be improved even though the products produced are good, in addition to competitive prices for the quality of similar products (Nike) so that consumers' intention to repurchase increases.

For further researchers, it is expected to conduct research specifically on the type of Adidas brand shoes. In this study in the future it is also necessary to use other variables such as store image, price, and sales promotion, so that it can enrich the information obtained.

Research Implications. The implications of this study include two things, namely, theoretical implications and practical implications that emphasize the tangible benefits of the results of this study to increase customers in Adidas brand shoes. Companies should maintain a good brand image through good product quality so that customers have the intention to buy back Adidas brand shoes. Some implications of the results of this study are factors that influence repurchase intention in this research are product quality and brand image. Theoretical implications related to repurchase intentions consistently reinforce the previous theory that product quality and brand image affect customers to the emergence of intentions to repurchase. In addition, brand image variables are able to mediate the influence of product quality on repurchase intention. The better the quality of products owned by Adidas brand shoes, it will be able to increase a good brand image and the brand image has an important role in influencing the intention to repurchase Adidas brand shoes. This supports the research that has been revealed in the research hypothesis, so it can be concluded that this study supports and clarifies the relationship between the variable brand images, product quality, and repurchase intention.

Research Limitations. It is important to realize that there are some limitations of this study which include this research only carried out at a certain point in time, while the environment can change at any time, which makes this research important to be done again in the future. Lack of variables, where there are still other variables that can affect repurchase intentions such as store image, price, and sales promotion. This research has 
not been specific, because it is carried out on all types of Adidas brand shoes, while Adidas brand shoes have many types of brand shoes.

\section{REFERENCES}

1. Ackaradejruangsri, P. 2013. The Effect of Product Quality Attributes on Thai Consumers' Buying Decision. Ritsumeikan Journal of Asia Pasific Studies, Vol.33, HIm.14-24.

2. Adil, M. 2012. The Influence of Brand Image on Sales. Journal of Basic and Applied Scientific Research, Vol.2, No.4, HIm.3552-3556.

3. Ain, N. dan Ratnasari, R.T. 2015. Pengaruh Citra Merek Melalui Sikap Konsumen Terhadap Niat Beli Ulang Pada Produk Busana Muslim Zoya di Surabaya, JESTT, Vol.2, No.7.

4. Andriadi, A. dan Untarini, N. 2013. Pengaruh Persepsi Kualitas Layanan dan Citra Merek Telkom Flexi Terhadap Niat Beli Ulang. Jurnal Ilmu Manajemen. Vol.1, No. 2.

5. Anggitan, A. R. 2013. Analisis Pengaruh Kualitas Produk, Harga dan Promosi Terhadap Loyalitas Pelanggan Dengan Minat Beli Ulang Sebagai Variabel Intervening. Jurnal Manajemen, Vol.7, No.9, HIm.1-18.

6. Anis, L. M., Suharyono dan Sunarti. 2015. Pengaruh Kualitas Produk Terhadap International Brand Image Serta Dampaknya Terhadap Keputusan Pembelian Mahasiswa Pembeli dan Pengguna Laptop Lenovo di Fakultas IImu Administrasi Universitas Brawijaya. Jurnal Administrasi Bisnis, Vol.28, No.2, Malang.

7. Amryyanti, R. 2013. Pengaruh Kualitas Layanan, Produk, dan Kewajaran Harga Terhadap Kepuasan dan Loyalitas Pelanggan Pada LnC skin care Singaraja. E-Jurnal Ekonomi dan Bisnis Universitas Udayana, Vol.2, No.1, HIm.22-29.

8. Aryadhe, P. dan Rastini, N.M . 2016. Kualitas Pelayanan, Kualitas Produk dan Citra Merek Terhadap Niat Beli Ulang di PT. Agung Toyota Denpasar. E-Jurnal Manajemen Unud. Vol. 5, No. 9.

9. Bahar, A. dan Sjaharuddin, H. 2015. Pengaruh Kualitas Produk dan Kualitas Pelayanan Terhadap Kepuasan Konsumen dan Minat Beli Ulang. Jurnal Organisasi dan Manajemen: Sekolah Tinggi IImu Ekonomi Bongaya Makassar, Vol.3, HIm.14-34.

10. Bruhn, M., Schoenmueller, V. And Schäfer, D.B. 2012. Are Social Media replacing traditional media in terms of brand equity creation. Management Research Review, Vol. 35, No. 9, HIm. 770-790.

11. Chaudhuri, A. and Ligas, M. 2009. Consequences of value in retail markets. Journal of Retailing, Vol.85, No.3, HIm.406-419.

12. Chen, T.Y., Yeh, T.L. and Jheng, W.S. 2013. Factors influencing brand association. African Journal of Business Management. Vol.7, No.19, HIm. 1914-1926.

13. Dharma, Ngakan Putu Surya Adi dan I Putu Gde Sukaatmadja. 2015. Pengaruh Citra Merek, Kesadaran Merek, dan Kualitas Produk terhadap Keputusan Membeli Produk Apple. E -Jurnal Manajemen Unud, Vol 4 No 10, 2015. ISSN : 2302 - 8912. Pg 32283255

14. Ehsani, Z. and Ehsani, M.H. 2015. Effect of Quality and Price on Customer Satisfaction and Commitment in Iran Auto Industry. International Journal of Service Sciences, Management and Engineering. Vol.5, No.1, HIm.5256.

15. Evelina, N., Waloejo, H.D. dan Listyorini, S. 2013. Pengaruh Citra Merek, Kualitas Produk, Harga, dan Promosi Terhadap Keputusan Pembelian Kartu Perdana Telkom Flexi (Studi Kasus pada Konsumen Telkom Flexi di Kecamatan Kota Kudus Kabupaten Kudus). Jurnal IImu Administrasi Bisnis, Vol.1, No.1, HIm.203-213.

16. Fouladivanda, F., Pashandi, M.A., Hooman, A. and Khanmohammadi, Z. 2013. The Effect of Brand Equity On Consumer Buying Behaviour In Term of FMCG In Iran, Vol.4, No.9, HIm.1-13.

17. Halim, B.C., Dharmayanti, D. dan Brahmana, R.K.M.R. 2014. Pengaruh Brand Identity terhadap Timbulnya Brand Preference dan Repurchase Intention pada Merek Toyota. Jurnal Manajemen Pemasaran Petra, Vol.2, No.1, HIm.1-11.

18. Hasan, A. 2013. "Marketing Cetakan Pertama". Media Pressindo. Yogyakarta. 
19. Idris, H.N.A. 2013. Pengaruh Kualitas Produk Citra Merek, Harga dan Promosi Terhadap Keputusan Pembelian Mobil Jenis Mpv Merek Toyota Kijang Innova di Semarang. Diponegoro Journal Of Management. Vol.2, No.3.

20. Kotler, P. (2012). Manajemen Pemasaran Perspektif Asia (Pertama). Yogyakarta: Andi.

21. Kotler, P. Dan Keller, K.L. 2012. Marketing Management (14th ed.). New Jersey: Pearson Prestice Hall.

22. Kotler, P. dan Amstrong, G. 2014. Prinsip-prinsip Marketing, Jakarta: Salemba Empat.

23. Kraim, H.S. 2011. The Influence Brand Loyalty on Cosmetics Buying Behavior of UAE Female Consumers. International Journal of Marketing Studies, Vol.3, No.2, HIm.123133.

24. Laura, S.N. dan Ringo, S.N.S. 2017. Pengaruh Kualitas Produk dan Kunggulan Bersaing Terhadap Keputusan Pembelian dengan Citra Merek Sebagai Variabel Intervening, Journal of Management and Business Review, Vol.14, No.2, Jakarta: Universitas 17 Agustus 1945 Jakarta.

25. Madahi, A. and Sukati, I. 2012. "The Effect of External Factors on Purchase Intention amongst Young Generation in Malaysia", International Business Research, Vol.5, No.8.

26. Musay, F.P. 2013. Pengaruh Brand Image terhadap Keputusan Pembelian (Survei Pada Konsumen KFC Kawi Malang). Jurnal Administrasi Bisnis Universitas Brawijaya. Vol.3, No.2.

27. Naufal, F.M. dan Widiyanto, I. 2014. Analisis Pengaruh Brand Awareness, Norma Subyektif, Keyakinan Label Halal terhadap Brand Attitude untuk Meningkatkan Minat Beli Ulang Kosmetik Merek Wardah. Jurnal Manajemen.Vol.16, No.5.

28. Noerchoidah. 2013. Analisis Pengaruh Harga, Kualitas Produk dan Iklan Terhadap Brand Image dan Keputusan Pembelian Sepeda Motor Merek Kawasaki. Jurnal WIG, Vol.3, No.1.

29. Paul, J. P. dan Olson, J. 2013. Perilaku Konsumen dan Strategi Pemasaran. Dialih bahasakan oleh Diah Tantri Edisi 9-Buku 1. Jakarta: Salemba Empat.

30. Puspita, L.,Yulianto, E. dan Sunarti. 2016. Pengaruh Kualitas Produk dan Word Of Mouth terhadap Keputusan Pembelian (Survei Kepada Konsumen Charles \& Keith di Tunjungan Plaza Surabaya), Jurnal Administrasi Bisnis (JAB), Vol. 34, No. 1, Malang: Universitas Brawijaya Malang.

31. Ramadhan, A.G. dan Sentosa, S.B. 2017. Analisis Pengaruh Kualitas Produk, Kualitas Pelayanan, dan Citra merek Terhadap Minat beli Ulang Pada Sepatu Nike Running di Semarang Melalui Kepuasan Pelanggan Sebagai Variabel Intervening. Diponogoro Journal Of Management. Semarang : Universitas Diponogoro, Vol.6, No.1, HIm.1-12

32. Ranto, D.W.P. 2013. Menciptakan Islamic Branding Sebagai Strategi Menarik Minat Beli Konsumen. Jurnal Bisnis Manajeman Akuntansi, Vol.1, No.2 HIm. 1-11.

33. Riduwan dan Kuncoro, E.A. 2011. Cara Menggunakan dan Memakai Path Analysis (analisis jalur). Bandung : Alfabeta.

34. Rizan, M., Saidani, B. dan Sari, Y. 2012. Pengaruh Brand Image dan Brand Trust Terhadap Brand Loyalty Teh Botol Sosro Survey Konsumen Teh Botol Sosro di Food Court Itc Cempaka Mas, Jakarta Timur. Jurnal Riset Manajemen sains Indonesia (JRMSI). Vol.3, No.1, HIm.1-17.

35. Roslina. 2010. Citra Merek: Dimensi, Proses Pengembangan Serta Pengukuranya. Jurnal Bisnis Dan Manajemen. Vol.6, No.3,HIm. 333-346.

36. Saidani, B. dan Arifin, S. 2012. Pengaruh kualitas produk dan kualitas layanan terhadap kepuasan konsumen dan minat beli pada ranch market. JRMSI-Jurnal Riset Manajemen Sains Indonesia, Vol.3, No.1, HIm.1-22.

37. Sari, A.K. 2013. Pengaruh Citra Merek dan Keluarga Terhadap Keputusan Pembelian Honda Beat. Jurnal IImu Manajemen, Vol.1, No.1, HIm.285-296.

38. Shahrinaz, I., Kasuma, J., Yacob, Y., Rahman, D.H.A.A. dan Mahdi, A.F. 2016. Relationship and Impact of E-WOM and Brand Image Towards Purchase Intention of Smartphone. Journal of Scientifc Research And Development, Vol.3, No.5, HIm.117-124.

39. Sunyoto, D. 2013. Teori, Kuesioner \& Analisis Data. Yogyakarta:Graha Ilmu. 
40. Tariq, M.I., Nawaz, M.R., Nawaz, M.M and Butt, H.A. 2013. Customer Perceptions about Branding and Purchase Intention: A Study of FMCG in an Emerging Market. Journal of Basic and Applied Scientific Research, Vol. 3, No.2, HIm. 340-347.

41. Thakur, S. and Singh, A. P. 2012. Brand Image, Customer Satisfaction and Loyalty Intention: A Study in The Context of Cosmetic Product Among The People of Central India. International Journal of Multidisciplinary Management Studies, Vol.2, No.5, HIm. 22498834.

42. Tjahjaningsih, E. dan Yuliani, M. 2009. Analisis Kualitas Produk dan Citra Merek dalam Mempengaruhi Keputusan Pembelian dan Dampaknya Terhadap Loyalitas Merek HP Nokia.TEMA, Vol.6, No.2, HIm.104-118

43. Widyastuti, P. dan Alwani. 2018. Peran Community Advice Sebagai Pemoderasi Dalam Keputusan Pembelian. Jurnal Manajemen dan Pemasaran Jasa. Universitas 17 Agustus 1945 Jakarta, Vol. 11, No. 1, HIm. 67-80

44. Wijaya, M. dan Jasfar, F. 2014. Pengaruh Rancangan Situs, Harga Kepercayaan, dan Keamanan Terhadap Pembelian Produk Fashion Melalui Online Shopping. Jurnal Manajemen dan Pemasaran Jasa, Vol.7, No.2, HIm. 31-62.

45. Wijaya, T. 2015. Pengaruh Service Quality Perception dan Satisfaction Terhadap Repurchase Intention. Modus Jurnal Ekonomi dan Bisnis, Vol.17, No.1, HIm. 39- 52.

46. Yunus, A. 2014. Pengaruh Kualitas Produk, Lokasi dan Lingkungan Fisik Terhadap Pembelian Ulang Pada Warung Kopi Harapan J2 di Kota Palu. E-Jurnal Katalogis. Universitas Tadulako, Vol.2, No.7.

47. Yusmawan., S., Kumadji, S. dan Rahardjo. 2014. Journal of The Effect of The Product Quality Mediation And Brand Image on The Influence of Pricing Policy And Service Quality Towards Trust. Journal of Contemporary Research In Business,

48. Zulfadly, E. 2013. Pengaruh Kualitas Produk, Harga dan Brand Image terhadap Keputusan Pembelian Ulang Produk Yakult di Kota Padang. Jurnal Manajemen, Vol.2, No.1. 